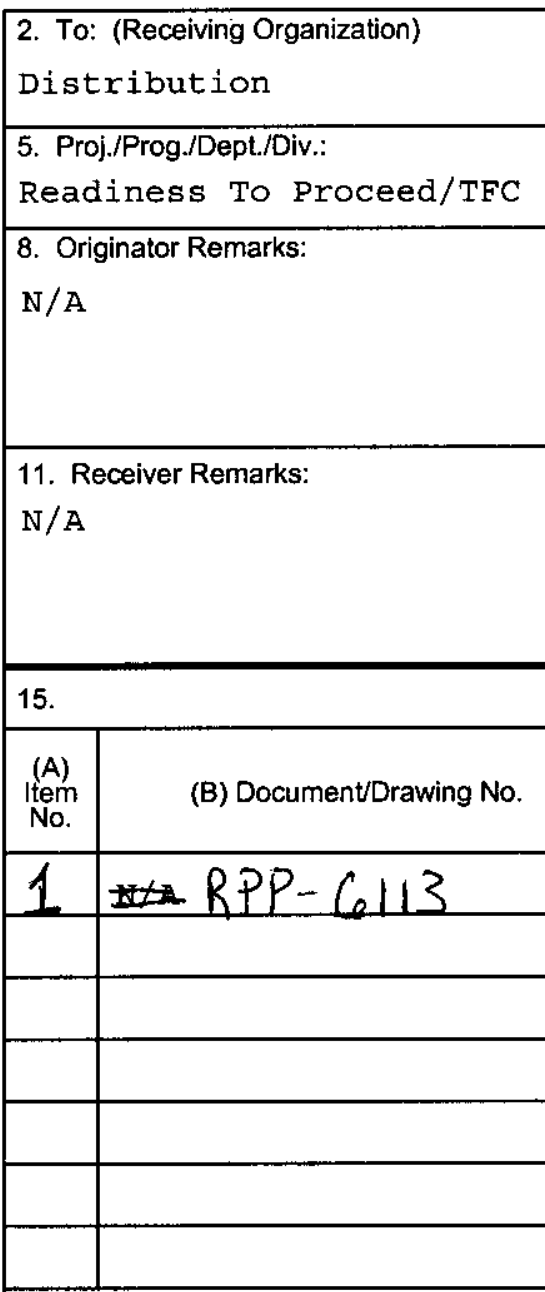

16.

Approval Designator (F)

E, S, Q, D OR N/A (See WHC-CM-3-5, Sec. 12.7)

1. Approval
2. Release
3. Information

17.

\begin{tabular}{|c|c|c|}
\hline $\begin{array}{l}\text { (G) } \\
\text { Rea- } \\
\text { son }\end{array}$ & $\begin{array}{l}(\mathrm{H}) \\
\text { Disp. }\end{array}$ & (J) Name \\
\hline & & Design Authority \\
\hline & & Design Agent \\
\hline 2 & 1 & Cog. Eng. L.C. Me \\
\hline 2 & 1 & Cog. Mgr. T.M. Ba \\
\hline & & QA \\
\hline & & Safety \\
\hline & & Env. \\
\hline 18. & & \\
\hline $\begin{array}{l}\text { Sign } \\
\text { Orig }\end{array}$ & $\begin{array}{l}\text { re of } \\
\text { tor }\end{array}$ & DT \\
\hline
\end{tabular}

11A. Design Baseline Document? $\square$ Yes $\square$ No

3. From: (Originating Organization)

Project Business Management

6. Design Authority/Design Agent/Cog. Engr.:

L.C. Mercado/T. M. Bateman

KEY

Reason for Transmittal (G)
4. Review
5. Post-Review
6. Dist. (Receipt Acknow. Required)

\section{SIGNATURE/DISTRIBUTION}

(See Approval Designator for required signatures)

(See Approval Designator for required signatures)

\begin{tabular}{|l|l|} 
4. Related EDT No.: \\
N/A \\
7. Purchase Order No.: \\
N/A \\
$\begin{array}{l}\text { 9. Equip./Component No.: } \\
\text { N/A }\end{array}$ \\
$\begin{array}{l}\text { 10. System/Bldg./Facility: } \\
\text { N/A }\end{array}$ \\
12. Major Assm. Dwg. No.: \\
N/A \\
13. Permit/Permit Application No.: \\
N/A \\
14. Required Response Date: \\
N/A
\end{tabular}

4. Related EDT No:

$\mathrm{N} / \mathrm{A}$

$\mathrm{N} / \mathrm{A}$

9. Equip./Component No:

$\mathrm{N} / \mathrm{A}$

$\mathrm{N} / \mathrm{A}$

12. Major Assm. Dwg. No.

N/A

13. Permit/Permit Application No.

\begin{tabular}{|c|c|c|c|c|c|c|}
\hline \multicolumn{3}{|c|}{ DATA TRANSMITTED } & (F) & (G) & (H) & (I) \\
\hline $\begin{array}{l}\text { (C) Sheet } \\
\text { No. }\end{array}$ & $\begin{array}{l}\text { (D) Rev. } \\
\text { No. }\end{array}$ & (E) Title or Description of Data Transmitted & $\begin{array}{l}\text { Approval } \\
\text { Desig- } \\
\text { nator }\end{array}$ & $\begin{array}{l}\text { Reason } \\
\text { for Trans- } \\
\text { mittal }\end{array}$ & $\begin{array}{c}\text { Origi- } \\
\text { nator } \\
\text { Dispo- } \\
\text { stion }\end{array}$ & $\begin{array}{c}\text { Receiv- } \\
\text { er } \\
\text { Dispo- } \\
\text { sition }\end{array}$ \\
\hline & 0 & Project Delivery & & & & \\
\hline & & Acquisition and & & & & \\
\hline & & Contracting plan for the & & & & \\
\hline & & Tank Farm Contractor & $\mathrm{N} / \mathrm{A}$ & 2 & 1 & \\
\hline & & & & & & \\
\hline & & & & & & \\
\hline & & & & & & \\
\hline
\end{tabular}

Disposition $(\mathrm{H})$ \& (I)

1. Approved

2. Approved w/comment 3. Disapproved w/comment
4. Reviewed no/comment

5. Reviewed w/comment 6. Receipt acknowledged

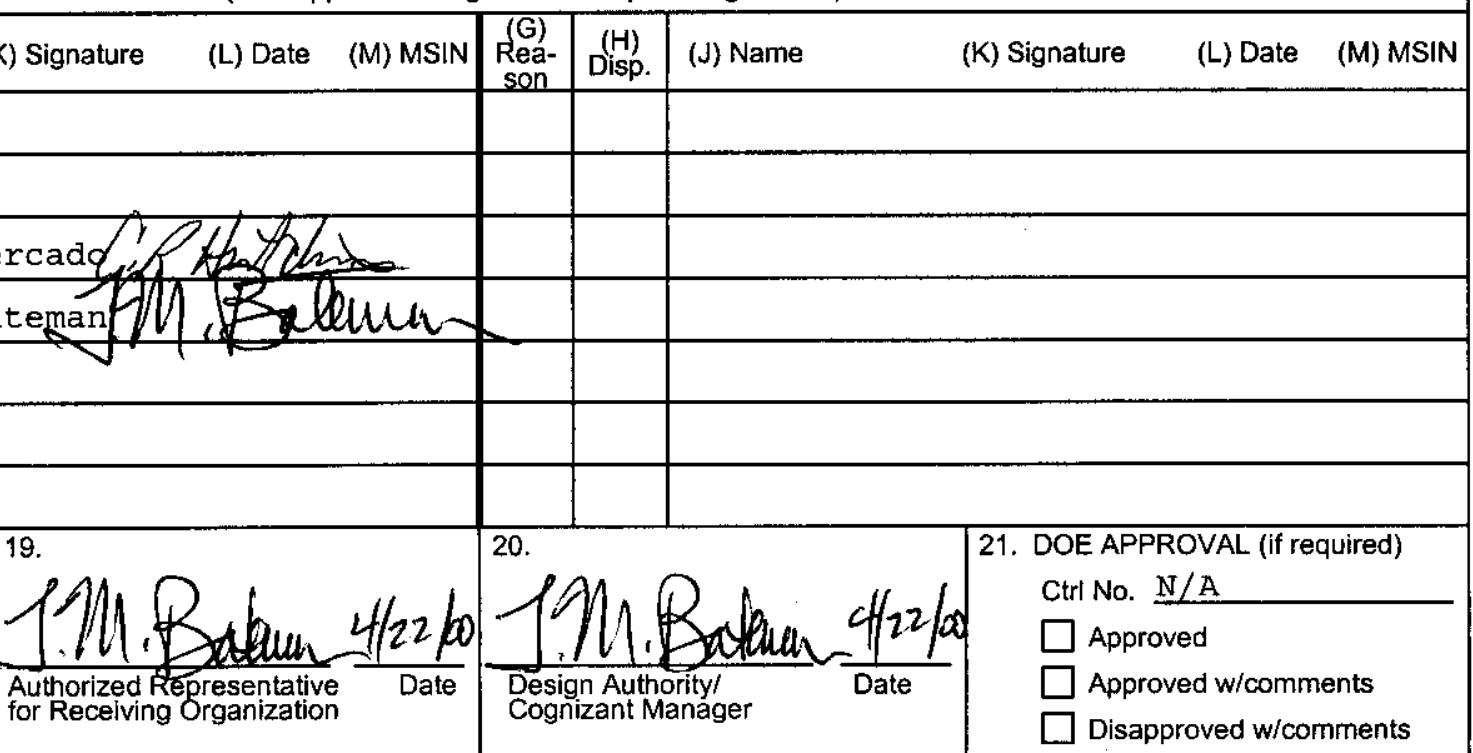




\title{
Project Delivery Acquisition and Contracting Plan for the Tank Farm Contractor
}

\author{
L. C. Mercado \\ CH2M HILL Hanford Group, Inc. \\ Richland, WA 99352 \\ U.S. Department of Energy Contract DE-AC06-99RL14047 \\ EDT/ECN: 629530 \\ UC: 2030 \\ Cost Center: 71300 \\ B\&R Code: EW3130010 \\ Charge Code: 108521 /AA3C \\ Total Pages: 40
}

Key Words: contracts, contracting

\begin{abstract}
:
This document is a plan presenting the process, strategies and approaches for vendor contracting by the Tank Farm Contracor. The plan focuses on contracting structures, practices, methods, and desired approaches in contracting.
\end{abstract}

TRADEMARK DISCLAIMER. Reference herein to any specific commercial product, process, or service by trade name, trademark, manufacturer, or otherwise, does not necessarily constitute or imply its endorsement, recommendation, or favoring by the United States Government or any agency thereof or its contractors or subcontractors.

Printed in the United States of America. To obtain copies of this document, contact: Document Control Services, P.O. Box 950, Mailstop H6-08, Richland WA 99352, Phone (509) 372-2420; Fax (509) 376-4989.

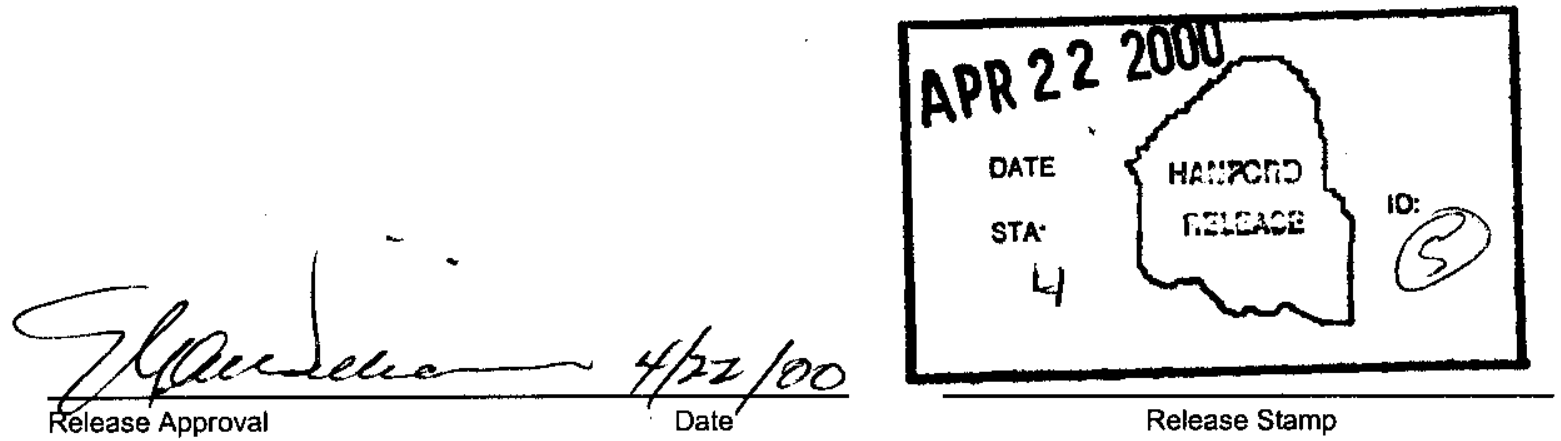


RPP-6113

Revision 0

Project Delivery

Acquisition and

Contracting Plan for the

Tank Farm Contractor

Prepared for the U.S. Department of Energy

Assistant Secretary for Environmental Management

\section{CH2MHILL Hanford Group, Inc.}

Richland, Washington

Contractor for the U.S. Department of Energy

Office of River Protection under Contract DE-AC06-99RL14047

Approved for Public Release; Further Dissemination Unlimited 
LEGAL DISCLAIMER

This report was prepared as an account of work sponsored by an agency of the United States Government. Neither the United States Government nor any agency thereof, nor any of their employees, nor any of their contractors, subcontractors or their employees, makes any warranty, express or implied, or assumes any legal liability or responsibility for the accuracy, completeness, or any third party's use or the results of such use of any information, apparatus, product, or process disclosed, or represents that its use would not infringe privately owned rights. Reference herein to any specific commercial product, process, or service by trade name, trademark, manufacturer, or otherwise, does not necessarily constitute or imply its endorsement. recommendation, or favoring by the United States Government or any agency thereof or its contractors or subcontractors. The views and opinions of authors expressed herein do not necessarily state or reflect those of the United States Government or any agency thereof.

This report has been reproduced from the best available copy.

Available in paper copy and microfiche.

Available electronically at

http://www.doe.gov/bridge. Available for a

processing fee to the U.S. Department of Energy and its contractors, in paper, from:

U.S. Department of Energy

Office of Scientific and Technical information

P.O. Box 62

Oak Ridge, TN 37831-0062

phone: $865-576-8401$

fax: 865-576-5728

email: reports@adonis.osti.gov(423) 576-8401

Available for sale to the public, in paper, from:

U.S. Department of Commerce

National Technical Information Service

5285 Port Royal Road

Springfield, VA. 22161

Phone: 800-553-6847

fax: 703-605-6900

email: orders@ntis.fedworid,gov

online ordering:

http://www.ntis.gov/ordering.htm 
RPP-6113

Revision 0

\section{Project Delivery Acquisition and Contracting Plan for the Tank Farm Contractor}

Prepared by:

L. C. Mercado

CH2M HILL Hanford Group, Incorporated

Date Published

April 2000

Prepared for the U.S. Department of Energy

Assistant Secretary for Environmental Management

\section{CH2MHILL}

Hanford Group, Inc.

P. O. Box 1500

Richland, Washington

Contractor for the U.S. Department of Energy

Office of River Protection under Contract DE-AC06-99RL14047

Approved for Public Release; Further Dissemination Unlimited 
RPP-6113 REV 0

This page intentionally left blank. 


\section{RPP-6113 REV 0}

\section{CONTENTS}

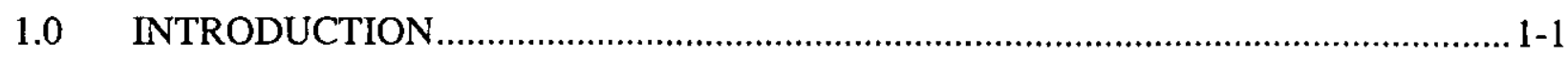

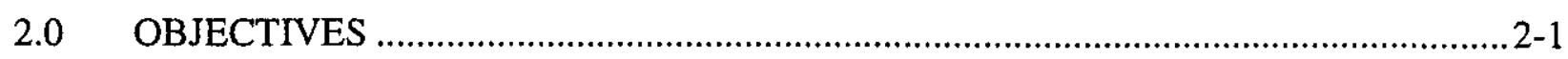

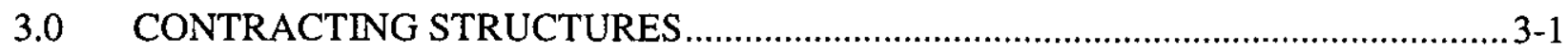

3.1 FIXED-PRICE CONTRACTS .................................................................

3.1.1 Firm-Fixed-Price Contracts...................................................................

3.1.2 Fixed-Price Incentive Contracts ......................................................... 3-1

3.2 COST-REIMBURSEMENT CONTRACTS ............................................. $3-1$

3.2.1 Cost-Plus-Fixed-Fee Contracts ........................................................... 3-2

3.2.2 Cost-Plus-Incentive-Fee Contracts.....................................................3-2

3.2.3 Cost-Plus-Award-Fee Contracts............................................................ 3-2

3.3 PERFORMANCE-BASED INCENTIVE CONTRACTS ................................... 3-2

3.4 ADDITIONAL CONTRACTING MECHANISMS ............................................ 3-3

3.4.1 Cost Contracts ..................................................................................... 3-3

3.4.2 Time-and-Materials Contract ............................................................ 3-3

3.4.3 Letter Contract............................................................................. 3-3

3.4.4 Basic-Ordering Agreement …….......................................................... 3-3

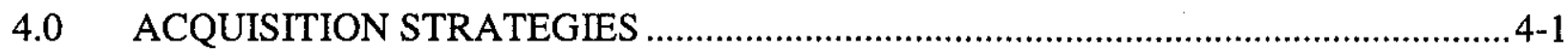

4.1 ARCHITECT/ENGINEER POOL UTILIZATION_........................................ 4-1

4.1.1 Assignment of Work Within the ArchitecttEngineer Pool.........................4-1

4.1.2 ArchitectlEngineer Pool Member Proposal Preparation Costs ..................4-1

4.1.3 Competition Among the ArchitectlEngineer Pool Members ....................4-2

4.1.4 Size and Composition of Task Orders......................................................4-2

4.1.5 Maximizing Use of the ArchitectlEngineer Pool ....................................4-2

4.1.6 Architect/Engineer Source Selection Board...........................................4-2

4.2 COMPETITIVE BID OUTSIDE ARCHITECT/ENGINEER POOL …..............4-3

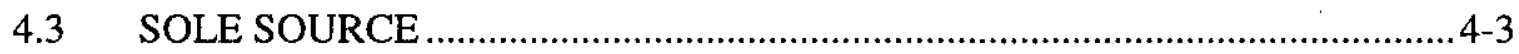

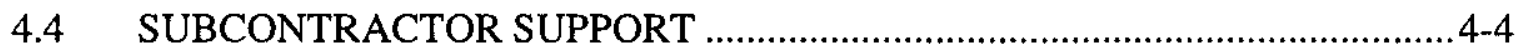

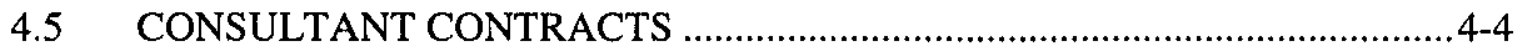

4.6 CONTRACT SELECTION FACTORS......................................................... 4-4

4.6.1 Ability to Meet Project Technical and Schedule Objectives.....................4-4

4.6.2 Price Competition.............................................................................. $4-4$

4.6.3 Cost Analysis................................................................................... 4-4

4.6.4 Type and Complexity of the Requirement ..............................................4-5

4.6.5 Urgency of the Requirement ..................................................................

4.6.6 Period of Performance or Length of Production Run .............................. 4-5

4.6.7 Contractor's Technical Capability and Financial Responsibility..............4-5

4.6.8 Concurrent Contracts.............................................................................. 4-5

4.6.9 Extent and Nature of Proposed Subcontracting ......................................4-5

4.6.10 Acquisition History ...............................................................................4-5

4.7 CONTRACTOR LIABILITY .................................................................... $4-6$ 
4.8 APPROVAL AUTHORITY ........................................................................

4.8.1 CH2M HILL Hanford Group, Inc., Authority/Process ..............................4-6

4.8.2 Office of River Protection Authority/ Requirements ................................4-7

4.9 PRE-ACQUISITION REVIEW/APPROVAL OF ITEMS AND

4.10 EQUIPMENT/PROCUREMENT STRATEGY …......................................... $4-8$

4.10.1 Material Procurement Contracts........................................................4-8

4.11 PROCUREMENT CYCLE .......................................................................

4.12 OTHER FACTORS AND TOOLS FOR CONSIDERATION ……………….... 4-8

5.0 COST CONSIDERATION - APPLICATIONS FOCUSSED ……….......................... 5-1

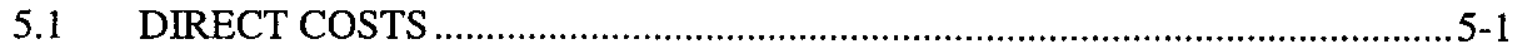

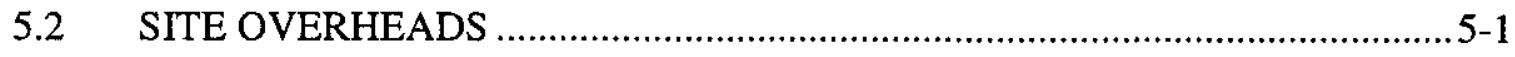

5.3 CONTRACT INCENTIVES .................................................................

5.3.1 Cost Incentives ................................................................................ 5-1

5.3.2 Performance Incentives .................................................................

5.3.3 Delivery Incentives ........................................................................ $5-2$

5.3.4 Multiple Incentive Contracts .............................................................5-2

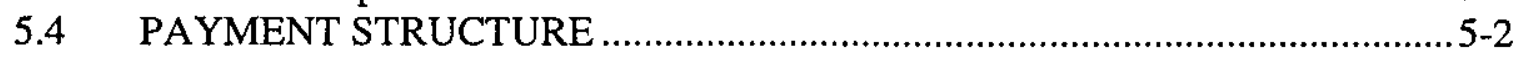

5.5 ACCRUAL REQUIREMENTS ……................................................... $5-2$

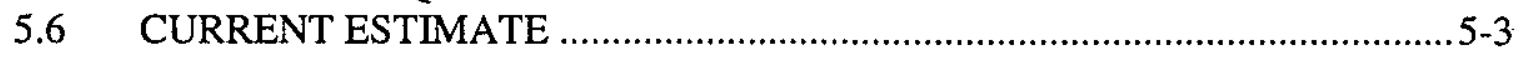

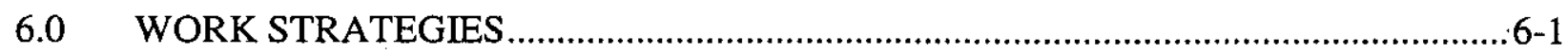

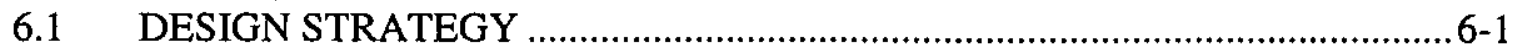

6.1.1 Project W-314 Detailed Designs ..........................................................6-1

6.1.2 Project W-211 Detailed Design.................................................................6-1

6.1.3 Project W-521 Detailed Design........................................................... 6-2

6.1.4 Project W-464 Detailed Design...........................................................6-2

6.1.5 Project W-520 Conceptual Design Report and Detailed Design ..............6-2

6.1.6 Project W-523 Conceptual Design Report and Detailed Design ............. 6-2

6.1.7 Project W-YYY Conceptual Design Report and Detailed Design............6-3

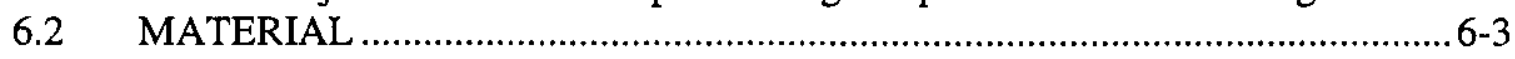

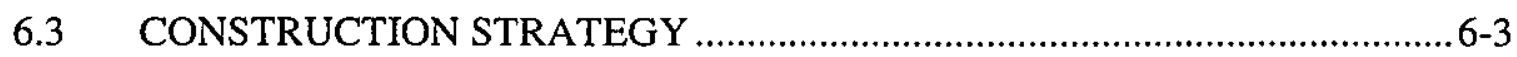

6.3.1 In-Farm Construction Work .................................................................6-4

6.3.2 Outside Farm or Clean Construction.................................................... 6-4

6.3.3 Construction Improvement Strategies ....................................................6-4

6.3.4 Construction Resources Needed...........................................................6-4

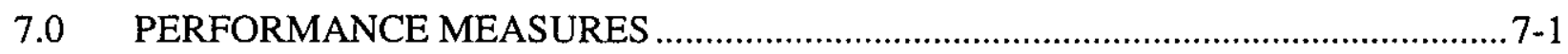

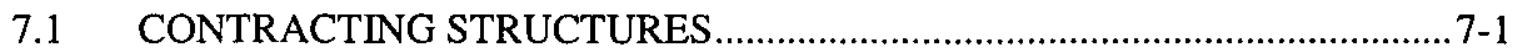

7.2 COST SAVINGS/REDUCTION ……....................................................

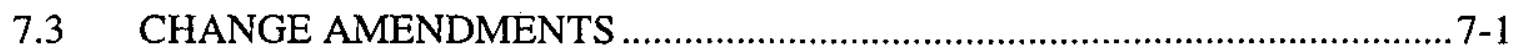

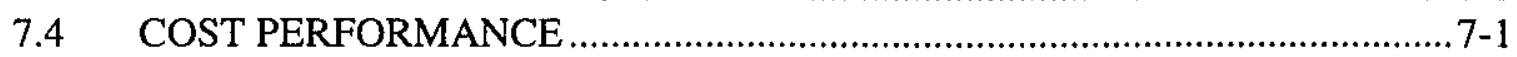

7.5 SCHEDULE/MILESTONE PERFORMANCE ............................................ 7-1

7.6 TECHNICAL PERFORMANCE ............................................................ 7-2

7.7 NEGOTIATED INCENTIVES ...................................................................

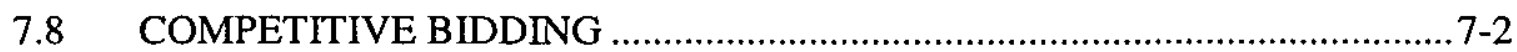




\section{FIGURES}

Figure 1-1. Contract Management Document Hierarchy and Process......................................1-2

Figure 4-1. Major Construction Contracting Process Flow Diagram. 
RPP-6113 REV 0

\section{TERMS}

$\mathrm{A} / \mathrm{E}$

$\mathrm{CHG}$

DOE

FFS

ORP

TFC
Architect/Engineer

CH2M HILL Hanford Group, Inc.

U.S. Department of Energy

Fluor Federal Services

Office of River Protection

Tank Farm Contractor 


\subsection{INTRODUCTION}

The U.S. Department of Energy (DOE), Office of River Protection (ORP) has contracted with the CH2M HILL Hanford Group, Inc. (CHG), as the Tank Farm Contractor (TFC), to support vitrification of Hanford Site tank waste by the Privatization Contractor. During Waste Feed Delivery Phase 1, waste will be retrieved from certain double-shell tanks and delivered to the Privatization Contractor to meet contract feed delivery requirements. Near-term project goals include upgrading infrastructure systems; retrieving and delivering the waste; and accepting the waste packages for interim onsite storage and disposal.

Project Delivery includes individual projects assigned to provide the infrastructure and systems responsible to provide engineering, design, procurement, installation/construction, and testing/turnover of systems for retrieval of waste from Hanford double-shell tanks. This plan sets the requirements for projects work scope, contracting practices, structures, methods, and performance measurements. The plan is designed to integrate Life-Cycle Projects acquisitions and provide a consistent contracting approach. This effort will serve as a step improvement in contract reform implementing commercial practices into DOE projects.

CH2M HILL Hanford Group's role in the tank farms is shifting primarily to one of preparation for retrieval of waste and construction of disposal facilities for vitrified waste. Work that is done will be prioritized against these primary missions. Some specific areas that are being analyzed are decisions concerning what work can be accomplished with CHG forces as opposed to outside contractors, each individual's role and the overall organizational skill mix for the changing mission, and establishment of an organization that focuses on project mission accomplishments rather than ongoing activities. Figure 1-1 shows the contract management document hierarchy and process. 
Figure 1-1. Contract Management Document Hierarchy and Process.

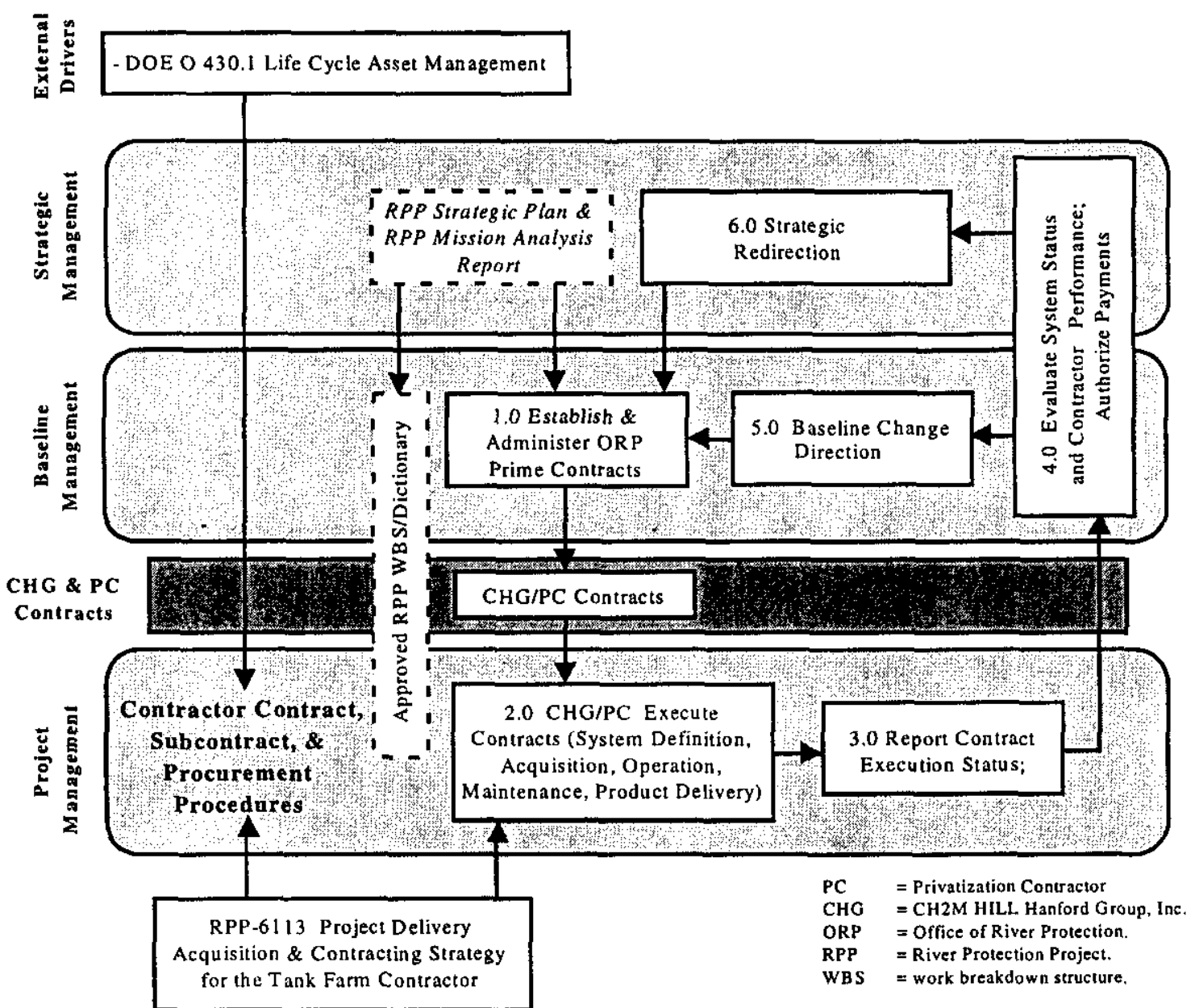

$6113-1 \cdot 1-R$ 


\subsection{OBJECTIVES}

The objectives of this project delivery acquisition and contracting strategy are as follows:

- Continue contract reform through the following elements:

- Increased competition

- Measurable cost reduction

- Cost avoidance though management focus

- Increased use of fixed-priced and incentive contracts

- Performance criteria and measures

- Performance based incentives

- Results-oriented statements of work/contract awards

- Integrate project delivery/activities/acquisitions in a consistent approach

- Reduce project costs through an integrated approach and strategy applying general commercial practices to procurements

- Provide projects with the tools necessary for a successful acquisition to support completion of project objectives

- Competitively bid major awards of contracts. 
RPP-6113 REV 0

This page intentionally left blank. 


\subsection{CONTRACTING STRUCTURES}

Establishing an effective contract type and negotiating prices are closely related and will be considered together. The objective is to obtain a contract type and price (or estimated cost and fee) that will result in reasonable contractor risk and provide the contractor with the greatest incentive for efficient and economical performance. The procurement organization and the requesting project will work together to determine the best method for achieving the desired results.

Measurable objectives need to be built into the contract. These will include milestones and measurements from beginning to end and allow for true performance measurement on a monthly basis.

\subsection{FIXED-PRICE CONTRACTS}

If appropriately used, fixed-price contracts can result in lower costs to the project; if inappropriately used, they can result in cost overruns, project delays, and litigation. The skills required to manage a fixed-price contract are very different from those required for cost-plus-award-fee or cost-plus-fixed-fee contracts. If a design-build contractor is brought on early in the project, as is often desirable, some form of cost-plus contract may be more appropriate, or a combination of cost-plus contracting that can be transitioned to a fixed-price contract as the design is defined.

When project requirements recur, or when quantity production begins and/or continues, the cost can appropriately be shifted to the vendor through the use of a fixed-price contract.

\subsubsection{Firm-Fixed-Price Contracts}

A firm-fixed-price contract provides for a price that is not subject to any adjustment on the basis of the contractor's cost experience in performing the contract. This contract type places on the contractor maximum risk and full responsibility for all costs and resulting profit or loss. It provides minimum administrative burden on the contracting parties.

\subsubsection{Fixed-Price Incentive Contracts}

A fixed-price incentive contract is a fixed-price contract that provides for adjusting profit and establishing the final contract price by a formula based on the relationship of final negotiated total cost to total target cost or other incentives.

\subsection{COST-REIMBURSEMENT CONTRACTS}

Cost-reimbursement types of contracts provide for payment of allowable incurred costs, to the extent prescribed in the contract. These contracts establish an estimate of total cost for the 


\section{RPP-6113 REV 0}

purpose of obligating funds and establishing a ceiling that the contractor may not exceed (except at its own risk) without the approval of the contracting officer.

\subsubsection{Cost-Plus-Fixed-Fee Contracts}

Cost-plus-fixed-fee contracts are structured so that most legitimate costs are reimbursable, with a predetermined fee added. These contracts are used when controlling costs is a lower priority than other factors, such as time. The open-ended reimbursement and fixed fee provide little incentive for the contractor to focus on the cost effectiveness or efficiency of his performance, and costs may grow as a result.

\subsubsection{Cost-Plus-Incentive-Fee Contracts}

A cost-plus-incentive-fee contract is a cost-reimbursement contract that provides for an initially negotiated fee to be adjusted later by a formula based on the relationship of total allowable costs to total targeted costs or other incentives.

\subsubsection{Cost-Plus-Award-Fee Contracts}

Cost-plus-award-fee contracts are similar to cost-plus-fixed-fee contracts except that the amount of fee payable (up to a limit specified in the contract) is subject to an assessment of contractor performance. Cost-plus-award-fee contracts are most suitable for projects with goals that are not as clearly definable in measurable and objective terms. These include ongoing work that does not have clearly defined end points, such as administrative support and research and development projects. Although the award fee offers flexibility to the contract manager by providing incentives for superior performance, the subjective nature of the award process makes it subject to possible disputes.

\subsection{PERFORMANCE-BASED INCENTIVE CONTRACTS}

The performance-based contract is a variation of the cost-plus-award-fee contract. Fees depend on the contractors meeting well-defined objectives of cost, schedule, and scope.

Performance-based contracts are suited to a large variety of activities for which performance objectives can be clearly stated and are measurable. The evaluation criteria and methods for measuring performance must be defined and agreed to by the project and the contractor; adjustments are made to reflect changing requirements (i.e., adverse events that are clearly 
beyond the contractor's control). Subjective performance evaluations and award fees are used only when the nature of the work does not lend itself to objective measurement. Types of incentives that can be structured into the contract include the following:

- Cost incentives

- Performance incentives

- Delivery incentives

- Multiple incentives.

\subsection{ADDITIONAL CONTRACTING MECHANISMS}

\subsubsection{Cost Contracts}

A cost contract is a cost-reimbursed contract in which the contractor receives no fee.

A cost contract may be appropriate for research and development work, particularly with nonprofit educational institutions or other nonprofit organizations, and for facilities contracts.

\subsubsection{Time-and-Materials Contract}

A time-and-materials contract provides for acquiring supplies or services on the basis of

- Direct labor hours at specified fixed hourly rates that include wages, overhead, general and administrative expenses, and profit

- Materials at cost, including, if appropriate, material handling costs as part of material costs.

\subsubsection{Letter Contract}

A letter contract is a written preliminary contractual instrument that authorizes the contractor to begin immediately manufacturing supplies or performing services.

\subsubsection{Basic-Ordering Agreement}

A basic-ordering agreement is a written instrument of understanding, negotiated between an agency, contracting activity, or contracting office and a contractor, that contains

- Terms and clauses applying to future contracts (orders) between the parties during its term

- A description, as specific as practicable, of supplies or services to be provided 


\section{RPP-6113 REV 0}

- Methods for pricing, issuing, and delivering future orders under the basic-ordering agreement.

A basic-ordering agreement is not a contract. 


\subsection{ACQUISITION STRATEGIES}

Projects requesting an acquisition (over $\$ 100,000$ for design or over $\$ 1,000,000$ for construction) will prepare a strategy/recommendation consistent with Sections 3.0 and 4.0 of this plan.

\subsection{ARCHITECT/ENGINEER POOL UTILIZATION}

Effective October 1, 1999, a pool of Architect/Engineer (A/E) service providers to support the needs of Hanford A/E services was established. The pool consists of COGEMA Engineering Corporation; Fluor Federal Services; Parsons, Holms \& Narver; and MACTEC-MEIER. The pool provides a competitive environment for A/E services and will be used whenever possible. Additional members may be added to the pool at a later time.

\subsubsection{Assignment of Work Within the Architect/Engineer Pool}

The determination and file documentation for assignment of work within the pool will be in accordance with the following criteria:

- Cost competition among the members will be a major consideration when work is awarded.

- Continuity between design phases to the extent practical will be ensured unless the providing $\mathrm{A} / \mathrm{E}$ fails to provide acceptable service. As an example, the $\mathrm{A} / \mathrm{E}$ doing the conceptual design will be considered for a detailed design and will provide engineering support until the task is completed.

- Past performance of pool members will be considered.

- The requesting organization, in accordance with established acquisition procedures, will be responsible for determining the reasonableness of the estimated cost for the task, including fee. The appropriate vehicle for the scope of work will be used in awarding tasks in accordance with the appropriate task order agreements.

- Sound business judgment will be used to award a task to a particular A/E provider and will include, as a minimum, consideration of technical qualifications, ability to meet the required schedule, and availability of resources to support the task requirements.

\subsubsection{Architect/Engineer Pool Member Proposal Preparation Costs}

Costs incurred by the A/Es for estimating task orders are reimbursable and will be paid by the requesting organization. 


\subsubsection{Competition Among the Architect/Engineer Pool Members}

For awards anticipated to exceed $\$ 100,000$, the requesting organization will compete task assignments among two or more A/Es in the pool or will address why this competition is not to be used in its strategy developed pursuant to article 4.0. The requesting organization will determine which $\mathrm{A} / \mathrm{Es}$ are included in the competition.

\subsubsection{Size and Composition of Task Orders}

The dollar value of individual task orders assigned to the $\mathrm{A} / \mathrm{E}$ pool is to be maximized to the extent possible to ensure the highest possible cost efficiency. Similar activities or phases associated with a specific task are to be consolidated into single task orders to minimize the total number of task orders and enhance the efficiency of task order management. To the maximum extent possible, the task orders will be for managed tasks and will not be placed solely for subcontractor support.

\subsubsection{Maximizing Use of the Architect/Engineer Pool}

CHG expects projects to maximize the use of the pool. Maximization includes using the pool members to perform tasks not included in the pool scope definition when a pool member is technically qualified to perform the task, the task does not conflict with another directed source of supply, and the pool member can meet the needs of the project. The projects are expected to be proactive in their definition of tasks so the pool members can perform them. Tasks are not to be written around specific individuals in the employ of non-pool members so that it becomes impossible for the pool to perform the work without subcontracting the work to the non-pool member. The projects are expected to plan far enough in advance to permit use of the pool and not to wait until the last minute so that requests to go outside the pool cannot be turned down without affecting the schedule requirements of the project.

\subsubsection{Architect/Engineer Source Selection Board}

In competing work among $\mathrm{A} / \mathrm{E}$ pool members, scopes of work greater than one million dollars will use an $A / E$ source selection board in the bid and award process. Board membership shall include the following:

- Project manager

- Procurement specialist (buyer)

- Business manager

- CHG senior manager

- Others as needed (e.g., quality assurance representatives, design engineer, contracts staff). 


\section{RPP-6113 REV 0}

\subsection{COMPETITIVE BID OUTSIDE ARCHITECT/ENGINEER POOL}

If an $\mathrm{A} / \mathrm{E}$ pool member cannot perform most of the work with its own staff, the requesting organization may go outside the pool with the prior approval of the $\mathrm{CHG}$ chief engineer and the director of Contracts and Procurement. To the extent possible, requesting organizations are expected to develop tasks in such a manner that the pool members can accomplish the work without having to subcontract the task.

\subsection{SOLE SOURCE}

Full and open competition will be used for contract actions. When not possible, sole source acquisition may be necessary. The approval of the chief financial officer is required for all sole-source contracts. A solid rationale for the noncompetitive acquisition $(>\$ 25,000)$ is required. A level of detail commensurate with the dollar value and complexity of the action (i.e., higher dollar value, more formal detail) is required. The following are guidelines for the information to be provided:

- Provide a brief, technical description of the supplies or services requested, including the application and any particularly significant or specialized characteristics or unique features. If a specific make and/or model is required, explain why.

- Present market survey results, previous price comparisons, service level evaluations, etc. If a market survey is not to be conducted, explain why and/or under what conditions such a survey will be conducted.

- For items or services having only one possible source, include a brief explanation of the facts, for example:

- Spare parts from an original equipment manufacturer

- Proprietary software and source code(s)

- Patent rights, copyrights, secret processes, etc.

- The proposed contractor has personnel considered to be leading experts or unique consultants

- Experience of a highly specialized nature possessed by the prospective contractor that is vital to the proposed acquisition.

- Provide an explanation of why the findings preclude competition and/or the preparation of a competitive specification or statement of work.

Failure to plan or lack of adequate internal resources is not a sufficient explanation. 


\subsection{SUBCONTRACTOR SUPPORT}

Subcontractor support related to in-house performance of engineering and project management capabilities covered by the scope of the $\mathrm{A} / \mathrm{E}$ pool must be obtained from within the pool. CHG expects task order releases to be structured as managed tasks to the extent possible. Individual expertise will not be purchased and subcontractor support services will be competitively bid. In addition, subcontractor support contracts will be used for short periods of time (normally 6 months or less).

\subsection{CONSULTANT CONTRACTS}

Subcontracts to hire consultants involve the hiring of specific individuals for their professional and specialized expertise. The definition of a consultant contract is a subcontract for the services of an individual (not a company) with specialized, recognized expertise. CHG Director approval is required when contracting for the services of a consultant.

\subsection{CONTRACT SELECTION FACTORS}

This section discusses the many factors that the project will consider in selecting and negotiating the contract type. The use of an evaluation board will be considered for major procurements, especially for $\mathrm{A} / \mathrm{E}$ work.

\subsubsection{Ability to Meet Project Technical and Schedule Objectives}

The vendor selected will be one who has a high probability of meeting desired technical and schedule objectives of the contract scope to be awarded.

\subsubsection{Price Competition}

Normally, effective price competition results in realistic pricing, and a fixed-price contract is ordinarily in the project's best interest. Projects will compete for all awarded work.

\subsubsection{Cost Analysis}

In the absence of effective price competition, the cost estimates of the offeror and the project provide the bases for negotiating the contract pricing arrangements. It is essential that the uncertainties involved in performance and their possible effect on costs be identified and evaluated so that a contract type can be negotiated that places a reasonable degree of cost responsibility on the contractor. The estimated cost of the workscope, usually found in the technical basis requirements, will be used as the basis for analysis, along with other pricing expenses from the procurement organization. 


\subsubsection{Type and Complexity of the Requirement}

Complex requirements, particularly those unique to the project, usually result in greater risk assumption by the project. Vendor experience in the work will be considered.

\subsubsection{Urgency of the Requirement}

If urgency is a primary factor, the project may choose to assume a greater proportion of risk or it may offer incentives to ensure a timely contract performance.

\subsubsection{Period of Performance or Length of Production Run}

In times of economic uncertainty, contracts extending over a relatively long period may require economic price adjustment terms.

\subsubsection{Contractor's Technical Capability and Financial Responsibility}

Contractors will have a demonstrated technical capability and must be financially solvent.

\subsubsection{Concurrent Contracts}

If performance under the proposed contract involves concurrent operations under other contracts, the effect of those contracts, including their pricing arrangements, will be considered.

\subsubsection{Extent and Nature of Proposed Subcontracting}

If the contractor proposes extensive subcontracting, a contract type reflecting the actual risks to the prime contractor will be selected.

\subsubsection{Acquisition History}

Contractor risk usually decreases as the requirement is acquired repetitively. Also, product descriptions or descriptions of services to be performed can be defined more clearly. In short, the project's prior experience with the contractor will be a consideration. 


\section{RPP-6113 REV 0}

\subsection{CONTRACTOR LIABILITY}

Contract language for liquidated damages clauses will be used only under the following circumstances:

- When either the time of delivery or performance is such an important factor in the award of the contract that the project may reasonably expect to suffer damage if the delivery or performance is delinquent

- The extent or amount of such damage would be difficult or impossible to ascertain or prove.

In deciding whether to include a liquidated damages clause in a contract, the contracting officer will consider the probable effect on such matters as pricing, competition, and the costs and difficulties of contract administration.

\subsection{APPROVAL AUTHORITY}

\subsubsection{CH2M HILL Hanford Group, Inc., Authority/Process}

To ensure that CHG is successful in controlling funds and acquiring materials/services with the appropriate technical and quality levels, the following required minimum levels of approval are effective immediately. Contract requisitions and material requests entered into the Hanford Site PassPort database must include the following electronic routing approvals:

- Buyer technical representative to validate need, quantities, and requirements (services)

- Contract engineer to ensure technical specifications as applicable (materials)

- Business manager or designated budget analyst to verify funding and current year baseline plans

- Quality assurance representative to verify that material request meets quality specifications (e.g., Safety Class)

- Cost account/work package manager final approval authority tied to signature authority level (i.e., A/B/C/D)

- Director/manager if requisition/request exceeds cost account/work package manager signature authority

- Approval of acquisition strategy by director. 


\subsubsection{Office of River Protection Authority/ Requirements}

Approval of the ORP contracting officer is required for the thresholds listed below. The ORP requires written notification 30 days in advance of the award:

- Award of a purchase order, subcontract, or modification (increase or decrease) priced greater than or equal to $\$ 1,000,000$, including awards to Project Hanford Management Contract enterprise companies

- Issuance of intra-company work orders greater than $\$ 100,000$

- Non-competitive award of a purchase order or subcontract priced greater than or equal to $\$ 500,000$

- Award of any transaction that indemnifies the subcontractor in addition to the indemnities provided by the general provisions

- Award of purchase order or subcontract involving access to classified documents/ materials or special nuclear materials by a supplier that is foreign-owned, controlled or influenced (Foreign Ownership Control Influence); this requirement includes unescorted access to an access-controlled facility

- Settlement of any claim in an amount greater than or equal to $\$ 100,000$

- Any termination settlement

- Acquisition of, or modifications to acquisitions of, real property, as defined in "Acquisition, Use, and Disposal of Real Estate," Department of Energy Acquisition Regulation (DEAR) 48 CFR 917.74 , priced greater than $\$ 50,000$.

NOTE: The above thresholds may be changed from time to time by ORP Corporate Office.

\subsection{PRE-ACQUISITION REVIEW/APPROVAL OF ITEMS AND SERVICES}

Management Directive RPP-MD-110, Pre-Acquisition Review/Approval of Items and Services, (CHG 2000) mandates compensatory actions resulting from the EH-10, "Enforcement Action 1999-04," and an extent-of-condition review.

The management directive provides for revised review and approval requirements supplementing those specified in RPP-PRO-123, The Material Request/Purchase Requisition/Contract Requisition Process," (CHG 1999a) and RPP-PRO-335, Use and Control of Purchasing Card" (CHG 1999b). This management directive requires that the appropriate quality and safety reviews be obtained for items and services acquired and used in nuclear facilities. 
The requirements set forth in this management directive are intended to be an interim measure to effect immediate improvement in the requisition, review and approval process for items and services designated as Quality Levels 1,2, and 3 and to ensure that items and services are not procured under Quality Level 0 if intended for future use in Quality Level 1, 2, or 3 applications. This management directive will be cancelled on completion of corrective actions designed to effect permanent improvements in the implementation of the engineering process and appropriate application of quality levels in nuclear facility procurements.

\subsection{EQUIPMENT/PROCUREMENT STRATEGY}

To the extent possible, the project will purchase commercial-grade equipment and material on a competitive basis. Equipment that can be procured as catalog items while still meeting the requirements of the specifications will be used. Because it is desirable to obtain common equipment for the tanks, an option to furnish equipment to match the staggered schedule of the upgrades will be explored with each major supplier.

Construction of field-fabricated assemblies and systems also may be completed with the use of commercial-grade material.

\subsubsection{Material Procurement Contracts}

Material procurement contracts will be structured in package awards with options, whenever possible, for maximized value. An example is the award of a contract for a number of transfer pumps supporting multiple retrieval systems.

\subsection{PROCUREMENT CYCLE}

The complexity of the work, its value, and vendor availability will determine the length of time required before contract placement. This time will be factored in with contingency before the project need date to support its objectives. While individual procurement cycles vary, the times shown on Figure 4-1, Major Construction Contracting Process Flow Diagram, are the average time frames for $\mathrm{CHG}$ awards.

\subsection{OTHER FACTORS AND TOOLS FOR CONSIDERATION}

- Risk analysis

- Life-cycle cost analysis (i.e., acquisition, maintenance, operations, dispositions)

- Safety assessment

- Value engineering

- Systems engineering

- Configuration management. 


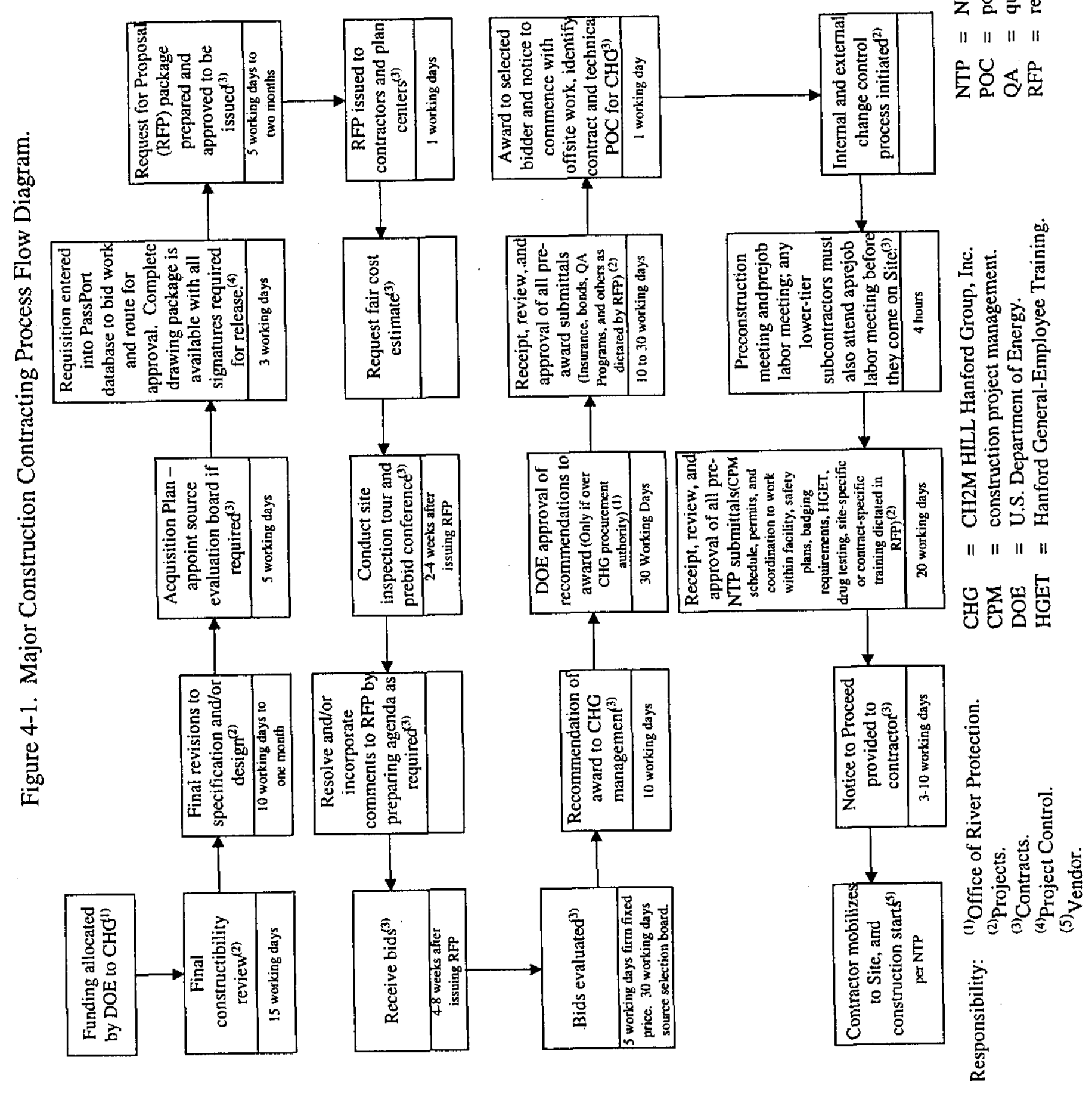


RPP-6113 REV 0

This page intentionally left blank. 


\subsection{COST CONSIDERATION - APPLICATIONS FOCUSSED}

\subsection{DIRECT COSTS}

Direct costs are labor hours at specified fixed hourly rates that include wages, overhead, general and administrative expenses, and profit. Direct costs will be negotiated up front and validated on a monthly basis, usually through the invoice process. Special attention will be paid to the allowability of home office hours/costs added to the direct costs (no overhead). In general, no more than $10 \%$ of these costs will be allowed unless specifically justified.

\subsection{SITE OVERHEADS}

CHG will add Site overhead to the direct costs to come up with a final cost known as the fully burdened programmatic cost. Overhead costs applied will vary as a function of vendor and company/organizational placement of contract. Contracts placed with Fluor Federal Services (FFS) receive an additional overhead in Project Furnished Services (i.e., government-furnished services). The adder is $1.3 \%$ for FFS as of March 2000 and is applied to actual direct costs as reflected in the Hanford Data Integrator (HANDI) database.

\subsection{CONTRACT INCENTIVES}

Contract incentives will be considered when the project work and the expected cost and schedule for normal performance with standard practices are well understood. Incentives will be considered when unique or innovative practices may provide desired performance improvement.

\subsubsection{Cost Incentives}

Most incentive contracts include only cost incentives, which take the form of a profit or fee adjustment formula and are intended to motivate the contractor to manage costs effectively. Incentive contracts may not provide for other incentives without also providing cost incentives (or constraints), except for fixed-price procurement.

\subsubsection{Performance Incentives}

To the extent practicable, positive and negative performance incentives will be considered in connection with contracts for performance of objectively measurable tasks when quality of performance is critical and incentives are likely to motivate the contractor. 


\section{RPP-6113 REV 0}

\subsubsection{Delivery Incentives}

Delivery incentives will be considered when improvement on a required delivery schedule is a significant project objective. It is important to determine the project's primary objectives in a given contract (e.g., earliest possible delivery or earliest quantity production).

\subsubsection{Multiple Incentive Contracts}

This type of contract motivates the contractor to strive for outstanding results in incentive areas and compels trade-off decisions among the incentive areas, consistent with the project's cost, the technical performance, and the delivery goals; a contract that emphasizes only one of the goals may jeopardize control over the others. Because outstanding results may not be attainable for each of the incentive areas, multiple-incentive contracts must include a cost incentive (or constraint) that operates to preclude rewarding a contractor for superior technical performance or delivery results when the cost of those results outweighs their value to the project.

\subsection{PAYMENT STRUCTURE}

Whenever possible, performance-based payments will be used in contracts. The basis for performance-based payments may be either specifically described events (e.g., milestones) or some measurable criterion of performance. Each event or performance criterion that will trigger a finance payment will be an integral and necessary part of contract performance and will be identified in the contract, along with a description of what constitutes successful performance of the event or attainment of the performance criterion. The signing of the contracts or modifications, the exercise of options, or other such actions will not be events or criteria for performance-based payments. An event need not be a critical event to trigger a payment, but successful performance of each such event or performance criterion will be readily verifiable.

\subsection{ACCRUAL REQUIREMENTS}

When work is performed as part of a service or equipment contract, there is generally no documented evidence of the activity in the financial system until the buyer receives an invoice from the contractor and approves it for payment (as opposed to "material" contracts where a receiving report is issued).

The invoice may arrive a number of weeks or months after the work has been performed. During this interim period, the buyer has an outstanding, but undocumented, obligation to pay the contractor. Because of the high dollar level of many service and equipment contracts, this outstanding obligation can be significant to performance measurement.

CHG has an obligation to DOE to report outstanding liabilities during the time period in which they are actually incurred. To account for these liabilities correctly, the accounting system requires that the estimated amount of liabilities be accrued.

These accruals are made monthly by the Accounts Payable organization to support monthly financial activity and are considered critical to obtaining accurate cost data, as they support the 
obligation of funds to cover undocumented payment obligations. Vendors will be required to submit monthly "estimated billings" in service and major equipment contracts. The budget analyst and buyer technical representative will review these and ensure that they are accurate.

\subsection{CURRENT ESTIMATE}

The value of the awarded contract will be analyzed against the current estimate usually found in the project's technical basis requirements, and/or approved estimate (e.g., conceptual design report, Title II Design). If the contract value is greater than $10 \%$ of the estimated cost, the analysis must justify the acceptability of placement of the contract. A baseline change request will be prepared (type and class to be determined) documenting the change and the area in which additional funds will be used for the increase. 
RPP-6113 REV 0

This page intentionally left blank. 


\subsection{WORK STRATEGIES}

\subsection{DESIGN STRATEGY}

Preference will be given to continuing the preliminary and detailed design with the same A/E based on the importance of maintaining continuity and performance of the work completed during conceptual design. In any event, the $\mathrm{A} / \mathrm{E}$ must have a proven record and must offer personnel experienced in similar design activities, with a preference shown for work on interfacing projects. To save costs, designs completed for companion projects will be considered for application when these designs are found to have potential applicability. Combining related design work from different projects will be considered when the timing and technical requirements permit. The following subsections discuss project design strategies that focus on the next five years.

\subsubsection{Project W-314 Detailed Designs}

Detailed designs are well under way for Project W-314. Three design projects are in progress: 244-S Double-Contained Receiver Tank Upgrades; Phase 1 Waste Tank Transfer System Upgrades; Phase 2 AP Tank Farm Upgrades. The A/E vendor for these is FFS. These designs are scheduled for completion by FY 2001 through a cost-plus type of contract. Five detailed design contracts remain to be awarded for the project. Incentive contracts, either cost-plus or fixed-price, will be used for these designs:

- Phase 2 AP Tank Farm Upgrades

- Phase 2 AY Tank Farm Upgrades

- Phase 2 AZ Tank Farm Upgrades

- Phase 2 AW Tank Farm Upgrades

- Phase 2 SY Tank Farm Upgrades.

Phase 2AP Tank Farm Upgrades are being evaluated for award to, or use of, the same vendor as Project W-521, AP Tank Farm Waste Feed Delivery System Upgrades. This contract will be placed in FY 2001.

The plan for remaining contracts is to use a competitive process through which to award remaining designs to one vendor to maximize efficiencies, compatibility, consistency, and resource leveling.

\subsubsection{Project W-211 Detailed Design}

Most of Project W-211 detailed designs are under way or completed. These designs are being done by $\mathrm{A} / \mathrm{E}$ vendor FFS under a cost-plus type of contract. This mechanism has been 


\section{RPP-6113 REV 0}

successful with FFS. For the two remaining detailed designs (AY-102 and AN-103 Retrieval Systems), the project may continue with the current $A / E$ vendor through an incentive cost-plus contract pool vendors.

\subsubsection{Project W-521 Detailed Design}

In early FY 2001, Project W-521 will need to commence definitive design on three retrieval systems (AZ-101, AN-101, AW-103), and AP tank farm lines to the Privatization Contractor's facility. The project will package the three designs into one bid and award package to be competed for A/E pool members. Fixed-priced contracting with incentives will be examined. Project W-211 design packages will serve as a benchmark. An A/E selection board will convene for the award. An option for a fourth design (AY-101) may be included; it will need to begin in FY 2002 (April 2002). Technical, cost, and schedule incentive parameters could be added for the fourth design award. The five remaining designs (SY-101, SY-103, AW-101, AW-104, AN -107) will be awarded in FY 2004. This schedule will allow proof of concept and lessons learned/enhancements to be incorporated into the remaining tanks.

AP farm waste feed delivery also will be awarded in early FY 2001. This design will be a separate contract award from the three initial retrieval systems. It is being evaluated for award with the Project W-314, Phase 2 AP Tank Farm Upgrades design, which also is expected to be awarded in FY 2001.

\subsubsection{Project W-464 Detailed Design}

Design-and-build contracting awards are being considered for facility types of structures (e.g., Project W-464) and for large individual procurements (transport systems) for which commercial standards exist. If these prove to be not cost effective, individual contracts will be competed and awarded. A decision on type of contracting strategy and mechanism for Project W-464 will be made in FY 2001.

\subsubsection{Project W-520 Conceptual Design Report and Detailed Design}

A conceptual-design contract for this project will be awarded in FY 2001. The bid and award cycle will begin in early FY 2001. It is expected to be competed among the $\mathrm{A} / \mathrm{E}$ pool members. A fixed-price incentive type of contract with advanced conceptual design as an option is expected to be awarded.

\subsubsection{Project W-523 Conceptual Design Report and Detailed Design}

A conceptual design report for Project W-523 will be competed among A/E pool members for award in the late summer of FY 2000. A fixed-price setup similar to that for the Project W-521 conceptual design report, awarded in October 1999, will be explored. 
Detailed designs for Tanks C-104 and C-107 will be packaged together for economy and efficiency in an award to be placed late in FY 2001. A fixed-price competition among A/E pool members, possibly to include outside firms, will be investigated.

\subsubsection{Project W-525 Conceptual Design Report and Detailed Design}

The award of conceptual design report and the detailed design option will maximize schedule compression in the award process. This process will begin in FY 2001. The scoped tank farm compliance upgrades will need to be completed by FY 2005. Experienced A/E vendors in tank farm work will be solicited for the award; this approach will minimize schedule and reduce risk.

\subsection{MATERIAL}

Commercial and industrial sources will be used to the extent possible for providing the retrieval system components or sub-systems. Advance procurement for the retrieval systems includes, but is not limited to, the following equipment and systems:

- Mixer pumps, transfer pumps, and other miscellaneous pumps

- Control systems

- Boilers for heating dilution fluid

- Burial containers and equipment

- Component removal equipment

- Closed circuit television and thermocouple assemblies.

CHG will provide procurement services for the above equipment and systems. Other materials and equipment required for construction will be procured by the construction vendor contractor.

For achieving cost and schedule efficiencies, long-lead procurement items will be grouped when possible for vendor award. Fixed-price contracting with qualified vendors for long-lead materials will be standard with options built into the contract award.

\subsection{CONSTRUCTION STRATEGY}

Project workscope will be grouped by tank farm and managed by tank farm construction managers. The integration will maximize cost and schedule efficiencies, effectively integrating tank farm work.

Field construction projects were analyzed for executability. Field cross-cutting activity (i.e., single-shell tank stabilization, transfers, characterization) constraints were inserted into construction schedules, and work activities were tied logically to support transfers to BNFL Inc. for waste vitrification. 


\section{RPP-6113 REV 0}

\subsubsection{In-Farm Construction Work}

CHG is implementing a farm-by-farm construction concept. The executability analysis grouped work activities by farm and developed logic-driven schedules for work optimization. Projects and operations were integrated into these logics. Future actions include the hiring of tank farm construction managers who will coordinate field construction work activities in these designated areas.

In-farm work will be done primarily by Projects W-314, W-211, W-521, and W-523. This work comprises tank farm upgrades (e.g., pits, lines, ventilation) and retrieval system construction/installation. Significant uncertainties exist in the performance of construction work in the tank farms. Because of these uncertainties, a cost-plus type of contract will be used in construction contract awards. To maximize efficiencies and effectiveness, incentives will be considered for these contracts. Areas for incentives are vendor performance, achievement of cost/schedule objectives, and safety performance.

\subsubsection{Outside Farm or Clean Construction}

A significant number of work activities will be performed outside the tank farms or in clean noncontaminated areas. A fixed-price incentive-type construction contract is planned for these work activities. Incentivised parameters to be included are cost, schedule, and safety performance. Construction vendor performance against these parameters will be taken into consideration in future awards.

\subsubsection{Construction Improvement Strategies}

Project W-314, which is leading the effort in field construction activities, is spearheading process improvements to maximize construction productivity. Improvements that have increased productivity include streamlining pre-job meetings, establishing large blocks of work, placing additional survey instruments in change trailers, and improving work package release and operational interfaces. Such enhancements are ongoing.

A formal lessons-learned process will be implemented for construction projects. Lessons learned from Project W-314 are being incorporated in Projects W-211 and W-521, specifically in the area of procurement and quality assurance.

Projects W-211 and W-521 have identified tank retrieval systems work scope that will be swapped between these two projects. Retrieval systems work involving tanks SY-102 and AY-102 will be moved to Project W-521, and that for tanks AZ-101, AN-101, AN-107 will be moved to Project W-211. This change will optimize design/construction by giving a tank farm project focus to the retrieval systems.

\subsubsection{Construction Resources Needed}

$\mathrm{CHG}$ is in the process of evaluating its construction work scope against the available supplier for step improvements. The current construction vendor's ability to achieve CHG's construction 


\section{RPP-6113 REV 0}

objectives while meeting cost, schedule, and technical goals is the primary focus. Changes will be forthcoming from $\mathrm{CHG}$ to strengthen the supplier contracting relationship and team with additional vendors if necessary. As part of construction contract awards, CHG will require vendors to submit a resource availability/acquisition evaluation.

Construction trade resources in the local area will be assessed in the next six months. The assessment will focus on the critical resources needed in construction activities and will identify potential shortfalls. Mitigating plans will be prepared and implemented for projected resource shortfalls. The community will be kept informed about expected levels of work/resources needed. This process will allow union halls to manage projected growth in required trades and will foster needed recruitment.

Further discussion on construction recruitment strategy is discussed in RPP-6114, Human Resources Staffing Plan for the Tank Farm Contractor (Bosley 2000). 


\section{RPP-6113 REV 0}

This page intentionally left blank. 


\subsection{PERFORMANCE MEASURES}

This Project Delivery Acquisition and Contracting Plan includes performance measures developed to support the goals and objectives established herein. Each performance measure evaluates, compares, and allows a judgment to be made as to whether the corresponding performance objective has been met. The goal is better management through focused analysis.

\subsection{CONTRACTING STRUCTURES}

Contract awards will be tracked through types of contingency structures (see Section 3.0). The goal is to increase the number of fixed-price contracts awarded except as noted in Tank Farms discussion, as these tend to lower project costs.

\subsection{COST SAVINGS/REDUCTION}

Performance measurement charts will track the value of contract awards against the current approved baseline. The goal is to award all contracts at $90 \%$ or less of the approved baseline.

\subsection{CHANGE AMENDMENTS}

Contract changes through amendments will be tracked two ways: (1) the number of project change amendments; (2) by type, the reasons for the change. Reasons for changes will be analyzed by root-cause methodology to improve contract performance.

\subsection{COST PERFORMANCE}

Cost performance will be tracked/reported against all major $(>\$ 100,000)$ cost type contracts: A monthly performance measurement will be agreed on with the vendor. A negative cost variance greater than $10 \%$ will require a corrective action plan from the vendor within ten working days after the end of the month in which the variance appeared.

\subsection{SCHEDULE/MILESTONE PERFORMANCE}

Schedule performance will be tracked/reported against major $(>\$ 100,000)$ cost type contracts. A monthly performance measurement will be agreed on with the vendor. A negative schedule variance greater than $10 \%$ will require a corrective action plan from the vendor within ten working days after the end of the month in which the variance appeared. 


\section{RPP-6113 REV 0}

\subsection{TECHNICAL PERFORMANCE}

Vendor technical performance must be measured to ensure product quality. While design, material, and construction vendors will be measured differently, common areas for focus will include quality, safety, and design changes.

\subsection{NEGOTIATED INCENTIVES}

The number of negotiated incentives will be tracked, with incentives met and not met tracked separately. Savings for met incentive and increases for incentives not met will be included in metric analysis.

\subsection{COMPETITIVE BIDDING}

The number of bidders per contract award will be tracked and measured. Increased competition spurs lower costs. The goal is to continually seek competition to maximize cost value. 


\section{RPP-6113 REV 0}

\subsection{REFERENCES}

48 CFR 917.74, "Acquisition, Use, and Disposal of Real Estate," Code of Federal Regulations, as amended.

Bosley, J. W., 2000, Human Resources Staffing Plan for the Tank Farm Contractor, RPP-6114, Rev. 0, CH2M HILL Hanford Group, Inc., Richland, Washington.

CHG, 1999a, The Material Request/Purchase Requisition/Contract Requisition Process, RPP-PRO-123, Rev. 0, CH2M HILL Hanford Group, Inc., Richland, Washington.

CHG, 1999b, Use and Control of Purchasing Card, RPP-PRO-335, Rev. 0, CH2M HILL Hanford Group, Inc., Richland, Washington.

CHG, 2000, Pre-Acquisition Review/Approval of Items and Services, RPP-MD-110, Rev. 1, CH2M HILL Hanford Group, Inc., Richland, Washington.

DOE O 430.1A, 1998, Life Cycle Asset Management, U.S. Department of Energy, Washington, D.C.

HANDI, n.d., Hanford Data Integrator, database maintained by CH2M HILL Hanford Group, Inc., Richland, Washington. 


\section{RPP-6113 REV 0}

This page intentionally left blank. 